\title{
Střední článek ve vzdělávání: vymezení pojmu, přístupy a implikace pro vzdělávací politiku
}

\author{
Arnošt Veselý \\ Univerzita Karlova, Fakulta sociálních věd
}

\begin{abstract}
Abstrakt: Střední článek (dále SČ) podpory nebo řízení je jedním z nejdiskutovanějších pojmů současné vzdělávací politiky, a to nejen v kontextu České republiky. Literatura na toto téma je ovšem velmi roztříštěná a pojem je často vymezován velmi odlišným způsobem, což značně komplikuje odbornou komunikaci. Článek sleduje dva cíle: 1) probíhající debatu o SČ ukotvit v odborné literatuře a podat její základní přehled; 2) zpřesnit užívanou terminologii a vymezit různé významy pojmu SČ. Struktura stati koresponduje s výše uvedenými cíli. Nejdříve popisuje metodologický př́stup využitý v textu a způsob výběru pramenů. Následuje základní vymezení sledovaného pojmu a jeho významu $v$ různých vzdělávacích systémech. $V$ další části studie je pak podán stručný kritický přehled odborné literatury. Jsou přitom odlišeny dva hlavní proudy, které jsou sice provázané, ale které je vhodné rozlišovat. Zatímco první typ literatury se primárně zabývá tím, co a jak SČ reálně dělá (výzkumně orientovaný proud), druhý typ se zaměřuje na to, co a jak by Sč dělat měl (prakticky orientovaný proud). Na základě předchozího rozboru je argumentováno, že lze odlišit nejméně čtyři různé významy pojmu SČ, zkráceně označené jako: (a) SČ jako volná sít’ místních aktérů; (b) SČ jako koordinovaný a interagující systém aktérů (široké pojetí školského obvodu); (c) SČ jako místně organizované uskupení několika klíčových organizací (užší pojetí školského obvodu); (d) SČ jako dekoncentrovaná instituce veřejné správy. Tyto čtyři významy jsou v textu podrobněji vysvětleny a je nabídnuta jejich pracovní definice. Stat' je uzavřena některými implikacemi pro užívání pojmu SČ ve vzdělávání v kontextu České republiky.
\end{abstract}

Kličová slova: střední článek, školský obvod, školský úřad, řízení vzdělávání

\section{Middle Layer in Educational Governance: Concept, Approaches, and Implications for Educational Policy}

Abstract: The concept of "middle layer" $(M L)$ is one of the most frequent terms in current education policy. Yet, the literature on the topic is fragmented and the concept itself is defined in several different ways which hinders effective discussion. The main goals of the article are as follows: 1) to imbed current discussion in the scholar literature and provide basic overview of scholar literature; 2 ) clarify the terminology and delimit various meanings of the "middle layer" concept. The article is structured as follows. First, the methodology of literature review is described. Then the basic meaning of $M L$ in various educational systems is explained. In the next part of the paper, the literature review on $M L$ is provided. In so doing, two strands of literature are distinguished. While the research-oriented strand focuses on analysis of what ML does (and does not), the practical stream relates to what ML should (or should not) do. Based on previous analysis, the paper argues that four meanings of middle layer can be delimited. These meanings are shortly labelled as follows: (a) a loose network of local actors; (b) a coordinated and interacting system of actors; (c) an organized set of several core local organizations; (d) a regional public administration institution. These four definitions are defined and explained. The article concludes with several implications for educational policy in the Czech Republic.

Keywords: middle layer, middle tier, school district, school office, education governance 
38 Sousloví „střední článek podpory“ nebo „střední článek řízeni““ se v poslední době stalo jedním z nejdiskutovanějších pojmů vzdělávací politiky v České republice (Hřebecký, 2019; Kitzberger, 2019; Trojan, 2020). Střední článek (dále jen „SČ“) se stal také jedním z důležitých návrhů představených v Hlavních směrech vzdělávací politiky ČR do roku 2030+ (Veselý et al., 2019) a následně ve Strategii vzdělávací politiky České republiky do roku 2030+ (MŠMT, 2020). Jde také o jedno z klíčových opatření této strategie, s jehož pilotním ověřením se $v$ příštích letech počítá. ${ }^{1}$ Idea zřizení SČ se však netýká jen aktivit státu. Podle podobné myšlenky je realizován také projekt Eduzměna, který usiluje o systémovou změnu v konkrétním území (Slejška, 2020). O důležitosti středního článku se nediskutuje jen v České republice. Řada uznávaných odborníků na vzdělávání upozornila v poslední době na klíčovou roli, kterou SČ může mít pro zlepšení vzdělávacích výsledků a snižení vzdělanostních nerovností (Fullan, 2015; Hargreaves \& Shirley, 2020). Nejde přitom pouze o teoreticky laděné texty. Apel na důležitost kvalitního řízení na střední úrovni najdeme zejména v řadě prakticky orientovaných dokumentů. Např́klad hojně citovaná studie Jak se systémy, které se ve světě nejvíce zlepšily, stále zlepšují [How the World's Most Improved School Systems Keep Getting Better] zmiňuje důležitost středního článku (middle layer) pro efektivní dosahování systémových vzdělávacích změn jako jedno ze svých nejzásadnějších zjišš̌ní:

To, co jsme neočekávali... je kritická role, kterou má střední (zprostředkující) článek mezi školou a centrem... Zjistili jsme, že dlouhodobé a udržitelné zlepšení celého systému vyžaduje integraci a propojení napřič všemi úrovněmi systému od školní třídy přes vedoucího školského obvodu (superintendanta) až do kanceláře ministra... (Mourshed et al., 2010, s. 81)

V jiné vlivné studii pak Schleicher (2015, s. 74) vyzdvihuje důležitost meso úrovně řizení pro dosažení změny ve vzdělávání.

V kontextu České republiky byla v rámci diskusí o SČ vyslovena celá řada očekávání, jak by měl střední článek vypadat a co vše by (ne)měl dělat. Debatuje se zejména o jeho konkrétních rolích a o tom, zda má jít o SČ podpory nebo řizení. Očekávání jsou však značně rưznorodá a místy až protichůdná. Problémem je, že individuální představy o podobě SČ jsou často jen implicitní a nedefinované. Zatímco na jedné straně myšlenkového spektra najdeme představu (byt' často nespecifikovanou), že SČ by měl v podstatě znamenat návrat zrušených školských úřadů, na druhé straně názorového spektra se setkáme $s$ názory, že SČ má v první řadě fungovat (pokud vůbec) na principu „zdola nahoru“, tedy na principu autonomie, resp. subsidiarity (Hřebecký, 2021).

Problém se vzájemným porozuměním při diskusích o Sč je dán i tím, že odborná literatura o tomto tématu je značně roztř̌šštěná, terminologicky nejednoznačná a často obtižně převoditelná do kontextu České republiky. Debaty o SČ jsou součástí širšího tématu education governance, kde je literatura taktéž velmi fragmentovaná,

1 Více na https://www.edu.cz/stredni-clanek-podpory/. 
a pokud je mi známo, neexistuje zde dokonce žádná přehledná srovnávací studie na toto téma. Stejně tak je to i s tématem SČ: výzkum je většinou omezen na Severní Ameriku a Velkou Británii (mnohdy pod jinými klíčovými pojmy), je velmi nesourodý, přičemž neexistuje žádná důkladná přehledová studie na toto téma (Greany, 2020, s. 4).

Cílem této stati je pomoci čtenářům zorientovat se v nepřehledné literatuře o SČ, a tím přispět ke strukturované a věcné debatě o možnostech i limitech zavádění Sč v České republice. Specifickými cíli této stati pak jsou: 1) ukotvit probíhající diskusi o SČ v odborné literatuře a podat její základní přehled; 2) zpřesnit užívanou terminologii a vymezit různé významy pojmu Sč. Vzhledem k rozsahu stati není cílem ani podat vyčerpávající přehled a srovnání literatury o SČ, ani navrhnout optimální model fungování Sč. Tam, kde je to možné, se ovšem snažím propojit aktuální českou diskusi s dostupnou literaturou.

Struktura stati koresponduje s výše uvedenými cíli. Nejdříve popisuje metodologický přístup využitý v textu a způsob výběru pramenů. Následuje základní vymezení sledovaného pojmu a jeho významu $v$ různých vzdělávacích systémech. V další části studie pak podávám stručný kritický přehled odborné literatury. Odlišuji přitom dva hlavní proudy literatury, které jsou sice provázané, ale které je vhodné odlišovat: výzkumně orientovaný proud a prakticky orientovaný proud. Na základě předchozího rozboru jsou v další části vymezeny čtyři možné významy pojmu SČ. Tyto čtyři významy jsou podrobněji vysvětleny a je nabídnuta jejich pracovní definice. Stat' je uzavřena některými implikacemi pro užívání pojmu SČ ve vzdělávání v kontextu České republiky. Argumentuji, že pro úspěšnou implementaci SČ v České republice je naprosto nezbytné vyjasnit si, o jakou podobu SČ usilujeme. Zároveň je třeba reflektovat, že jeho zřizení má řadu rizik a úskalí, o nichž je potřeba otevřeně a kriticky diskutovat. $Z$ tohoto důvodu $v$ závěru rozebírám také některé spíše problematické body v jeho zavádění tak, jak vyplývají z dostupné literatury.

\section{Metodologie}

Metodologie stati je založena zejména na kritickém studiu anglicky a česky psaných pramenů $\mathrm{k}$ tématu SČ ${ }^{2}$ Centrálním sledovaným konceptem je přitom pojem „střední článek ve vzdělávání“. Pro vytvoření vstupního korpusu článků jsem využil databázi SCOPUS. Jako vyhledávací pojmy jsem zvolil middle layer a middle tier a vyhledání jsem omezil na oblast společenských věd (která obsahuje také oblast vzdělávání). ${ }^{3}$ Vyhledávání jsem přitom neomezoval pouze na klíčová slova, ale vyhledával jsem výše uvedené sousloví v celém textu, protože jinak by došlo k velkému

2 Striktně vzato není tato stat' přehledovou studií. Z hlediska žánru má však nejbliže $\mathrm{k}$ tzv. mapujícímu přehledu, jehož cílem je analyzovat, roztřídit a shlukovat do větších celků rozsáhlejší soubor prací na dané téma. Závěry mapujícího přehledu pak slouží jako podklad pro jiné přehledy nebo pro orientaci dalšího výzkumu v dané oblasti (Mareš, 2013, s. 430).

3 Vstupní vyhledávací zadání bylo následující: ALL („Middle tier“) OR ALL („Middle layer“) AND (LIMIT-TO (SUBJAREA, „SOCI“). 
zúžení záběru. Tato vyhledávací strategie vedla k vygenerování 404 článků, jejichž abstrakty byly analyzovány $z$ hlediska jejich potenciální relevance $k$ danému tématu. $\checkmark$ prvním kole byly zahrnuty všechny studie, jejichž abstrakty pojednávají v nějakém kontextu o střední úrovni v organizaci vzdělávání, tj. všechny potenciálně relevantní studie z oblasti vzdělávání. První kolo vedlo k vygenerování 38 studií. Ačkoli vyhledávání nebylo omezeno rokem publikace, nejstarší relevantní text pochází z roku 2010. Viditelný nárůst prací nastává po roce 2018: nejvíce textů (8) je z roku 2020. To ukazuje na zvyšující se relevanci a zájem o téma Sč. Pokud jde o geografickou lokaci, většina článků (21) pochází z Velké Británie. Zajímavé je, že studie lze nalézt pod velmi různorodými klíčovými slovy, napríklad local authorities, educational improvement, system leadership, decentralization, networks, school effectiveness a mnohé další. Dokumenty se velmi lišily z hlediska své relevance. Některé se dotýkaly tématu SČ jen velmi okrajově v rámci analýzy jiného tématu (např. kurikula), nebo jen odkazovaly na studie, které měly hledané sousloví ve svém názvu.

Výše uvedených 38 studií bylo podrobeno další analýze z hlediska toho, zda obsahují podrobnější reflexi a vymezení pojmu SČ, a to bud' teoretické, nebo vytvořené na konkrétních příkladech. Tomuto kritériu vyhovělo jen 9 prací (Crawford et al., 2020; Forde \& Torrance, 2021; Glatter, 2021; González et al., 2020; Greany, 2020; Chapman, 2019; Chapman \& Hadfield, 2010; Levin, 2013; Simkins et al., 2015). Celkový soubor vstupních dokumentů se stal vodítkem pro vyhledávání dalších relevantních prací (zejména podle citované literatury). Jak jsem očekával, ukázalo se, že o tématu pojednává řada zdrojů skrze jiné centrální pojmy (především school districts, local education authorities, decentralization nebo leadership). Vyhledávání prostřednictvím těchto pojmů ovšem není možné, nebot' počet prací by byl př́liš vysoký a obsahoval by řadu textů s minimální, nebo nulovou relevancí pro tuto studii. ${ }^{4}$

Nejčastěji citované odkazy ze vstupního korpusu dokumentů jsem doplnil vyhledáváním slovníkových a přehledových hesel o school districts, př́ípadně dalšími pracemi, na které bylo odkazováno ve více publikacích ve vstupním korpusu. Vzhledem $\mathrm{k}$ tomu, že téma studie není doposud komplexně zpracováno (alespoň v angličtině či v češtině), bylo postupováno induktivním způsobem, kdy byla pramenná základna postupně rozšiřována $i \mathrm{v}$ průběhu psaní textu. Postupně se tak podařilo sestavit soubor prací, které jsou z hlediska vymezení konceptu SČ nejvíce relevantní a které byly podkladem pro zpracování této stati (více $v$ seznamu citované literatury na konci článku).

Vzhledem k šiři tématu a jeho neostrému ohraničení, vysoké variabilitě (a do jisté míry i absenci) relevantních zdrojů nebylo možné postupovat metodou př́mého a detailního porovnání pramenů. Jak je v článku uvedeno, téma SČ je navíc teoreticky slabě a povrchně rozpracováno, takže lze jen těžko tř́dit zdroje na základě odlišných teoretických předpokladů. Místo toho jsme se tedy zaměřili jen na elementární klasifikaci hlavních proudů literatury o SČ a vymezení hlavních odlišností z hlediska záběru a sledovaných cílů. Studium pramenů ukázalo, že existují dva

4 Gamson a Hodgeová $(2016$, s. 218) ve své přehledové studii o historii školských obvodů v USA uvádějí, že jen v databázi JSTOR je na toto téma kolem 62000 článků. 
hlavní cíle studií. První je převážně výzkumný, druhý je pak převážně praktický. Na základě těchto dvou základních cílů jsem pak dostupnou literaturu roztř́ílil do dvou základních proudů: výzkumně orientovaného a prakticky orientovaného.

Zatímco první proud se primárně zabývá tím, co a jak SČ reálně dělá, druhý proud se primárně věnuje tomu, co a jak by SČ dělat měl. První linie tedy představuje především teoreticky a empiricky laděnou literaturu o SČ (Anderson \& Young, 2018b; Spillane, 1996). Tento proud je sice často také prakticky orientovaný (např. ve své snaze identifikovat znaky efektivních školských obvodů), praktické implikace zde ovšem vycházejí z důkladné empirické analýzy. Primární referenční skupinou autorů tohoto typu literatury je odborná komunita a standardy (a čtenáři) odborných časopisů. Oproti tomu druhý směr je vyloženě prakticky orientovaný a jeho hlavním cílem je spíše preskripce optimálního nastavení a optimální role SČ (Fullan, 2015; Hargreaves \& Shirley, 2020). Primární referenční skupinou pro autory z této skupiny jsou praktici, zejména pak tvưrci vzdělávací politiky. Tento směr se pochopitelně opírá také o odborné teoretické i empirické poznatky. Hlavním zdrojem jsou zde ovšem praktické zkušenosti autorů (často poradců v oblasti vzdělávání) a také jejich hodnotové ukotvení a přesvědčení. Oba druhy literatury jsou užitečné a relevantní pro debatu o nastavení SČ v České republice. Oba mají ovšem také své limity a je třeba přistupovat $\mathrm{k}$ nim kriticky a s vědomím různých omezení těchto přístupů. Podrobný rozbor těchto proudů by si vyžádal samostatné pojednání. Pro přibližení hlavních témat a autorů věnuji každému proudu samostatný oddíl (viz dále oddíl 4).

\section{Základní vymezení pojmu střední článek}

Pro diskuse o SČ je charakteristická nejednotnost ve vnímání ústředního termínu. $\checkmark$ angličtině se lze setkat s různými pojmy: middle tier (Chapman \& Hadfield, 2010; Nordholm, 2016; Parkin, 2012), middle layer (Mourshed et al., 2010), meso level (Schleicher, 2015) nebo middle level (Hargreaves \& Shirley, 2020). ${ }^{5}$ Mnohé studie, které se konceptu SČ přímo týkají, s žádným obecným pojmem nepracují a místo toho užívají konkrétní pojmenování v daném geografickém kontextu (Leithwood et al., 2019; Spillane, 1996). Protože většina studií na téma SČ je z prostředí USA, Kanady nebo Velké Británie (Greany, 2020), ústředním pojmem je zde district nebo local education authority, což bychom do češtiny mohli přeložit jako školský obvod nebo okrsek. Obecnější pojem SČ často užívají texty, které chtějí být srozumitelné i mimo svůj regionální kontext. Je zajímavé, že k pojmu SČ se mnohdy uchylují autoři, kteří pojednávají o změně v řízení vzdělávací politiky a změnách struktur řízení. Situace, kdy zažité pojmy (jako local education authority) ztrácejí svůj tradiční význam, vedou $k$ potřebě reflexe střední úrovně rízení ve vzdělávání a zároveň pohledu mimo daný geografický kontext (Bubb et al., 2019; Greany, 2020; Lubienski, 2014).

5 V posledním př́padě jde pak především o spojení middle level leadership. 
Z výše uvedených důvodů neexistuje žádná široce akceptovaná definice SČ a neexistuje ani šiřeji sdílený př́stup $\mathrm{k}$ vymezení tohoto pojmu. Jak je uvedeno výše, nebyla dosud vytvořena ani žádná komplexnější souhrnná studie na toto téma. Vymezení pojmu je přitom složitější, než by se mohlo na první pohled zdát. Rorrerová et al. (2008, s. 311) např́klad uvádějí těžkosti s vymezením školského obvodu, protože ten podle nich může znamenat „superintendanta, školní radu, střední úroveň administrativy nebo území jako organizační jednotku“. Explicitní definici SČ tak nalezneme jen ojediněle. Podle Astonové et al. $(2013$, s. 1) se SČ rozumí „rozmanitá škála institucí, které působí mezi školami a centrální vládou, jejichž úkolem je podpořit zlepšování škol“. Zahrnuje místní školské okrsky, klastry škol, učitelské aliance, vzdělávací partnerství a další. Také Greany $(2020$, s. 3) záměrně definuje SČ širokým způsobem. Podle něj SČ „obsahuje jakýkoli aspekt podpory a vlivu působící mezi individuálními školami a centrální vládou, a to bez ohledu na to, zda je, či není právně ukotven“. Podle jiné definice, z kontextu Velké Británie, se jedná o „systém podpory a odpovědnosti (akontability), který propojuje veřejné školy zřizované místními školskými obvody s ministerstvem školstvi““ (Bubb et al., 2019, s. 13).

\section{Střední článek v různých vzdělávacích systémech}

Střední úroveň znamená $v$ různých zemích značně odlišné věci (obec, distrikt, region, provincii atd.). Věc se pak dále komplikuje tím, že na střední úrovni operuje většinou nikoli jeden subjekt, ale často více rozličných vzájemně propojených organizací. SČ je navíc vždy zasazen do politického a administrativního systému dané země. Úzce tedy souvisí se strukturou veřejné správy, celkovým nastavením řízení a vládnutí (governance) $v$ dané zemi. $Z$ tohoto důvodu neexistují např́č zeměmi dvě totožné podoby SČ. Roli SČ tak nelze pochopit bez znalosti odpovídajícího kontextu řizení vzdělávání a rozdělení kompetencí a odpovědností v daném systému, včetně jejich historického vývoje.

Účelem této studie není porovnávat řizení vzdělávání a role SČ v těchto různých systémech. To by si vyžádalo samostatnou monografii. Nelze ani zformulovat komplexní typologii SČ, které existují v různých vzdělávacích systémech, protože jednotlivé podoby Sč jsou velmi specifické. Pro přibližení tématu širšímu okruhu čtenářů ovšem považujeme za účelné, v návaznosti na Greanyho (2020, s. 3), odlišit alespoň tři základní podoby SČ (jakési ideální „weberovské“ typy SČ).

Prvnímu typu odpovídají země (Greany uvádí Austrálii, Singapur a Čínu), ve kterých je střední článek součástí centrální nebo provinční vlády. Toto uspořádání je typické pro země s centralizovaným vzdělávacím systémem. Zaměstnanci Sč jsou $v$ tomto př́padě přímo zaměstnanci státu (civil servants). Např́iklad ve většině států Austrálie představuje SČ regionální organizace centrálního ministerstva školství, které je nejen hlavním tvưrcem politiky, ale také poskytovatelem prostředků, zaměstnavatelem a vlastníkem všech budov (Levin, 2013, s. 74). 
Druhý typ reprezentují země, kde jsou zřizování a správa škol svěřeny městům a obcím, resp. místně zvoleným zastupitelstvům, která byla zvolena v komunálních volbách. Tato podoba Sč je typická pro většinu zemí v Evropě. Uvnitř tohoto typu však existuje vysoká variabilita. To je dáno jednak tím, že v řadě zemí existuje nikoli jeden, ale více stupňů místně volené samosprávy (kraje, regiony), jednak uspořádáním a velikostí těchto samosprávných jednotek. To lze ukázat např́klad na rozdílu mezi Finskem a Českou republikou. V obou těchto zemích plní roli SČ, pokud jde o základní školy, města a obce. Nicméně je zde jeden velký rozdíl. Zatímco měst a obcí je ve Finsku jen 311 (Bubb et al., 2019), v České republice je 6244 měst a obcí, přičemž 2533 z nich zřizují alespoň jednu základní školu. ${ }^{6}$ Velikost zřizovatelů přitom mưže mít velký vliv na jejich odborné kapacity. Je evidentní, že subjekt, který zřizuje například jen jednu školu, nemůže vytvořit takové odborné a podpůrné zázemí jako zřizovatel, který je větší. sč tedy mưže mít na povrchu relativně podobné rysy (např. z hlediska kompetencí a ukotvení v systému řizení dané země), ovšem jejich reálná role může být (a je) v každé zemi značně odlišná.

Třetí typ představují USA a Kanada, ve kterých SČ tvoři školské obvody, rízené školskými radami, volenými v místních volbách. Školské rady pak také rozhodují, mimo jiné, o personálním obsazení a správě školských obvodů, tj. o nevolených pozicích tzv. superintendantů. Na rozdíl od předchozího typu jsou ale volby do rad školských obvodů oddělené od místních voleb a školské obvody jsou oddělené od ostatních oblastí správy a samosprávy (Greany, 2020).

Uvedenou klasifikaci tří existujících Sč lze ovšem považovat pouze za orientační, nebot' podoba SČ je v rưzných zemích velmi rozmanitá a někdy obtížně zařaditelná mezi výše uvedené typy. González et al. (2020) například popisují nový systém SČ, k jehož zavádění dochází v Chile. Zde právě probíhá (v letech 2018-2025) reforma, během které je 345 místních školských úřadů nahrazováno 70 autonomními státními institucemi nazvanými Servicios Locales de Educación Pública (SLEPs). Tyto SLEPs jsou centrálně koordinovány ministerstvem školství a mají obsluhovat 35 až 140 škol v daném území (které tvoři v průměru pět měst a obcí). Jejich hlavním úkolem je podpora spolupráce škol a vytváření funkčních sítí škol v daném území. Centrálním principem zde není ani hierarchické řizení, ani tržní princip, ale nařizené sít’ování škol.

Pro pochopení role SČ je ovšem třeba znát nejen jeho současné nastavení, ale také jeho vývoj. Podoba SČ $v$ jednotlivých zemích se během času mění a trajektorie těchto změn je v rozličných zemích různá, což lze dokumentovat například na odlišném vývoji SČ v Kanadě a USA na straně jedné a ve Velké Británii na straně druhé.

V USA vznikaly školské obvody (school districts) „odspodu“. V důsledku toho jde o zcela nezávislé místně volené instituce, úzce propojené s místní komunitou (Sykes et al., 2009). Jejich velikost a pưsobnost tak mohou být diametrálně odlišné. ${ }^{7}$ Vzhledem $\mathrm{k}$ tomu, že původně se jednalo o velmi malé oblasti, došlo postupně

Údaj o počtu zřizovatelů pochází z nepublikovaného dokumentu, který poskytlo MŠMT v rámci prípravy Strategie vzdělávací politiky České republiky do roku 2030+.

7 Největši školský okrsek (New York City's School District) zahrnuje školy s téměř milionem žáků, zatímco nejmenší okrsek může být tvořen jen jednou malou školou. 
44 k jejich slučování („konsolidaci“) a snaze je více propojit se vzdělávací politikou na státní i federální úrovni. Důležité je ovšem především to, že historicky byly školské okrsky ustanoveny pro jiné účely, než jsou podpora a zlepšení výuky. Jejich primárním cílem bylo vytvořit místní politické a administrativní instituce, jejichž úkolem bylo zvládnout kvantitativní růst školského systému. Jejich úkol byl tedy hlavně administrativní, nikoli podpůrný (z hlediska vzdělávacích procesů). Požadavek, aby se zabývaly také kvalitou vzdělávání, vzdělávacími výsledky a zlepšováním žáků, se objevil relativně nedávno a školské okrsky na něj nebyly personálně ani strukturálně připraveny. Jejich organizační formy byly často značně byrokratické, založené na hierarchickém řízení a „hromadném zpracováni““ (batch processing) vzdělávaných dětí (Sykes et al., 2009, s. 770). Postoj mnoha odborníků ke školským distriktům tak byl v USA a Kanadě až donedávna velmi kritický (Spillane, 1996). Ještě na začátku devadesátých let 20. století byla role střední úrovně v USA, z hlediska pedagogického procesu, považována za prakticky bezvýznamnou. Za hlavního aktéra a hybatele vzdělávací politiky byly považovány školy. „Školy jsou v systému vzdělávání životně důležitým hybatelem, stát určuje celkovou politiku (a je hlavním pokladníkem). Vše mezi školou a státem není nijak podstatně důležité...“ (Finn 1991, cit. podle Rorrer et al., 2008, s. 3058). Přibližně od druhé poloviny poslední dekády 20. století ovšem začalo být na školské obvody pohliženo jinak, a to jako na instituce potenciálně podpůrné či vedoucí (leading). $V$ poslední době, zejména $v$ souvislosti se vznikem konceptu „vedení ze středu“, začíná být právě střední úroveň považována za klíčovou (Campbell \& Fullan, 2019).

V jiných zemích naopak dochází ke snaze roli SČ zmenšit nebo SČ nějak „obejít“ (bypass). Lubienski (2014) dokonce $v$ tomto ohledu mluví o de-intermediaci (dis-intermediation). Typickým príkladem je Anglie, kde již delší dobu dochází k zmenšování role místních školských úřadů (local education authorities, LEAs). Jejich role byla převedena jednak na školy samé (které tak získaly vyšší autonomii), jednak na úroveň státu (Greany, 2020). Reálné efekty této reformy a jí podobných jsou nejasné a mohou se lišit od deklarovaných cílů a očekávaných podob SČ. Greany a Higham (2018) např́klad o anglické reformě hovoří jako o „chaotické centralizaci“, v níz dochází k soupeření různých subjektů o autoritu a legitimitu.

\section{Střední článek v odborné literatuře}

\subsection{Výzkumně orientovaný proud}

Jak je uvedeno výše $v$ části věnované metodologii, $z$ hlediska sledovaných cílů lze $\checkmark$ zásadě odlišit dva hlavní proudy literatury: výzkumně orientovaný a prakticky orientovaný. $\mathrm{V}$ této části stručně shrneme témata a zjištění prvního $\mathrm{z}$ těchto dvou proudů.

Většina literatury o SČ je zaměřena na specifický kontext, zejména pak na USA a Velkou Británii, a lze ji dohledat spiše pod klíčovými slovy „školský obvod“ než pod 
pojmem SČ. Přestože je literatura o školských obvodech relativně početná, zdaleka není tak informačně bohatá jako například literatura o školách či vzdělávací politice na úrovni státu. I v USA, kde je výzkum SČ nejvíce rozvinut, má také literatura o SČ významná omezení. Často jde o dílčí případové studie vázané na konkrétní kontext (Sykes et al., 2009, s. 775). V tomto ohledu existují dvě podstatné výjimky v oblasti výzkumu SČ. První jsou studie, které se snaží empiricky měřit efektivitu školských obvodů a jejich vliv na výsledky žáků (district effectiveness; Anderson \& Young, 2018b; Ford et al., 2020). Druhým typem jsou pak studie, které se zabývají otázkou optimální velikosti SČ (Schiltz \& De Witte, 2017).

Pro účely této stati je relevantní hlavně první oblast věnovaná efektivitě školských obvodů. První větší studií na toto téma byla práce Murphyho a Hallingera (1988), následovaná pak zejména studiemi Leithwooda $(2010,2013)$. Nedávno k nim přibyly studie další (Anderson \& Young, 2018a, 2018b; Ford et al., 2020). Výsledkem těchto prací je pak především tzv. rámec efektivních distriktů, tedy popis toho, jaké praktiky a charakteristiky jsou typické pro školské obvody, které dosahují vysoké kvality ve vzdělávání a zároveň je v nich realizován spravedlivý přístup ke vzdělání (Anderson \& Young, 2018b; Leithwood, 2013; Murphy \& Hallinger, 1988). Mezi tyto hlavní charakteristiky patří například zaměření se na učení žáků a výuku, stanovení vysokých očekávaných výsledků, investice do pedagogického leadershipu, vytvoření a udržování dobré komunikace, spolupráce a vztahů (Anderson \& Young, 2018a). Výše uvedená literatura se opírá o syntézu řady empirických studií. I ta má ovšem svá omezení. Andersonová a Youngová (2018b) v důkladně provedené práci kupříkladu ukazují, že studie efektivnosti školských obvodů v USA jsou vychýlené jak z hlediska vybraného distriktu, tak sledovaných parametrů a metodologie (nadreprezentovány jsou zejména případové studie reformujících se okrsků v urbánních oblastech). Podle nich tedy nelze výsledky zobecnit na všechny obvody.

Hlavní problém nenormativně orientovaného výzkumu SČ je ovšem jiný, a to chybějící hlubší teoretické ukotvení. Literatura o SČ se odkazuje na různé teoretické přístupy, obzvláště z oblasti institucí a organizace (Nordholm, 2016; Sykes et al., 2009). Jde např́klad o teorii „institucionální volby“ (institutional choice), která se zabývá otázkou, jak dochází k alokaci autority a kompetencí mezi instituce, tedy jaké pravomoci a odpovědnosti jsou komu svěřeny (Clune, 1987). Vychází se přitom z předpokladu, že každá instituce má - $v$ rámci svého postavení v celém systému své výhody i nevýhody. Lokální instituce se kupříkladu mohou těšit větší dưvěře než instituce více vzdálené. Na straně druhé ovšem existují faktory jako „úspora z rozsahu“, tedy výhody spojené s tím, že provoz je realizován ve větším měřítku (Clune, 1987, s. 121).

V empirických studiích však chybí hlubší teoretické vysvětlení, proč a jakým způsobem distrikty ovlivňují kvalitu vzdělávání (Spillane, 1996). To ale neznamená, že $v$ pozadí těchto studií nejsou zjednodušené implicitní teorie. Stručně řečeno, v zásadě lze vysledovat dvě protichůdné logiky role SČ založené na dvou zcela odlišných teoretických předpokladech. Podle první teorie je nezbytné co nejužší propojení různých úrovní řizení: v tomto případě škol a státu. Zatímco stát je vybaven hlavními 
nástroji (zejména finančními a regulačními) a autoritou k vzdělávacím změnám, školy jsou nejdůležitějším místem změny, na které je potřeba klást hlavní odpovědnost. Tato teorie byla základem vzdělávacích reforem (nejen) v USA, založených na standardizovaných testech a zvýšené akontabilitě škol vưči státu (Sykes et al., 2009, s. 770). $\mathrm{K}$ tomu se přidávala kritika distriktů (podpořená nedůvěrou $\mathrm{k}$ nim) jako byrokratických institucí, které jen ztěžují komunikaci mezi centrem a školami - dvěma nejdůležitějšími institucemi. Výsledkem byla snaha obejít (bypass) distrikty jako instituce a snaha řídit školy přímo z centra, nebot' to bylo považováno za efektivnější (Elmore, 1993, s. 98).

Oproti výše uvedené logice ovšem stojí teoretický předpoklad, že distrikty mají oproti státní úrovni komparativní výhodu, a to především v tom, že jsou schopné lépe distribuovat zdroje (zejména ke školám, které to nejvíce potřebují), získávat politickou podporu v daném území a zprostředkovávat podporu školám (Sykes et al., 2009, s. 770). Tato druhá teorie (nebo spíše proto-teorie), tedy, že institucionální pozice distriktů je jedinečná, postupně získávala na váze, a to jak díky empirickým studiím prokazujícím, že SČ má reálný vliv na kvalitu vzdělávání, tak díky postupně propracovávaným normativním př́stupům (více v následující subkapitole).

\subsection{Prakticky orientovaný proud}

Současný zájem o SČ je veden spíše praktickými než výzkumnými důvody. Existuje několik faktorů, které přispěly $\mathrm{k}$ „renesanci“ zájmu o střední úroveň rízení ve školství. $V$ první řadě je to celosvětová snaha nalézt co nejefektivnější způsob řízení školství pro 21. století. Kontext, ve kterém se vzdělávací politika odehrává, se v posledních desetiletích radikálně proměnil (Burns et al., 2016; Burns \& Köster, 2016). Roste počet aktérů, kteří se na rozhodování o vzdělávání podílejí nebo chtějí podílet. Rostou i očekávání se vzděláváním spojená (Veselý, 2019). Jestliže otázka vzdělávání byla kdysi na periferii politického zájmu, dnes je vzdělávání často ústřední otázkou politických diskusí. Zvyšuje se také množství dat, informací a poznatků o vzdělávacích výsledcích a procesech. To všechno ve svých důsledcích vede $k$ tomu, že se vzdělávací systémy stávají čím dál komplexnějšími a složitějšími na řízení (Snyder, 2013; Wilkoszewski \& Sundby, 2014).

Zároveň se ukazuje, že neexistuje nějaké univerzálně platné nastavení řízení vzdělávací politiky. Neexistuje jedno „optimálni“ “ řešení, resp. návod na to, jak by mělo rozdělení odpovědností a způsob rrízení vypadat: téměř jakékoli struktury mohou být za určitých podmínek úspěšné - a naopak (Burns \& Köster, 2016, s. 109). Úspěšné mohou kupř́kladu být - a jsou - jak decentralizované, tak centralizované systémy. Např́klad vzdělávací systémy v Singapuru a Hongkongu si jsou kulturně velmi podobné a oba dosahuji výborných výsledků. Zatímco vzdělávací systém v Singapuru je velmi centralizovaný, Hongkong je př́kladem výrazně decentralizovaného systému (Whelan, 2009). Z toho ovšem zároveň vyplývá, že decentralizace ani centralizace nejsou samy o sobě zárukou efektivnějšího řizení. Vzdělávací systémy $\vee$ mnoha zemích prošly $\vee$ posledních desetiletích (zejména $\vee$ devadesátých 
letech 20. století) významnou decentralizací a převodem kompetencí na nižší úroveň (Neele-man, 2019; OECD, 2018), aniž by to mělo nějaký jednoznačný efekt na zlepšení vzdělávacích výsledků. Stejně tak ovšem nelze tvrdit, že by se osvědčily přístupy spočívající ve vyšší centralizaci a standardizaci. Vzdělávací politiky mnoha zemí tak prošly radikálními reformami bez toho, že by se situace ve školách skutečně zlepšila (Payne, 2008).

Hlavním důvodem zvýšeného zájmu o SČ je především hledání nového přístupu k řizení vzdělávání, který bude reagovat na neúspěch obou krajních strategií: shora dolů (top-down) i zdola nahoru (bottom-up). Hierarchický přístup shora dolů může dobře fungovat jen v situacích, v nichž je jasný účel a jasné měření výsledků, ovšem nikoli v systémech, kde jsou cíle komplexní a obtížně měřitelné (Hargreaves \& Ainscow, 2015, s. 43). Řízení výhradně shora je nemožné také proto, že nelze vždy domyslet všechny individuální aspekty a okolnosti ohledně učení žákủ a často vede i k autokratickému a neetickému jednání (Hargreaves \& Shirley, 2020, s. 93).

Řizení zdola nahoru, úzce propojené s myšlenkou decentralizace a maximální autonomie škol, má ovšem také své limity. Představa spontánního předávání inovací a příkladů dobré praxe se ukázala jako naivní (Hargreaves \& Shirley, 2020, s. 94). Ačkoli vysoká autonomie škol přispívá k inovaci v některých školách, tyto inovace se spontánně jen velmi málo rozšiřují do ostatních škol. To znamená, že strategie scale up (název lze volně přeložit jako strategii postupného rozšiřování), která je založena na předpokladu, že se inovace z jednotlivých škol bude volně šírit dále, až se dotkne většiny škol, podcenila složitost a komplexnost vzdělávací změny a sami autoři této myšlenky od ní postupně ustoupili (Elmore, 1996, 2016).

Shrnu-li výše uvedenou argumentaci: reformy prováděné shora jsou pro věk inovací a rozmanitosti nevhodné a strategie vycházející zdola zase nevedou k žádnému výraznému zlepšení v širším měřítku (Hargreaves \& Ainscow, 2015, s. 44). To, co logicky zbývá, je snaha zaměřit se na školské obvody, které se nacházejí v samém středu školského systému. Jak je uvedeno výše, lze se v tomto opř́t o dostupnou (byt' limitovanou) empirickou evidenci, ze které vyplývá, že školské obvody mohou být mocnou hybnou silou pozitivních změn ve vzdělávání (Leithwood, 2013). Otázka je, $v$ čem přesně by měla role Sč spočivat a co by měly reálně vykonávat. Kromě přístupů snažících se vymezit rysy úspěšných školských obvodů na základě empirické analýzy (viz výše) existují i normativní přístupy, které čerpají spíše z hodnot autorů, zkušenosti či anekdotické evidence. Mezi ně lze zařadit například vymezení hlavních rolí SČ ve vlivné studii Mourshedové et al. (2010, s. 73, 82). Podle nich má SČ plnit několik hlavních rolí: 1) poskytovat cílenou podporu školám; 2) umožnit komunikaci a tlumit konflikty mezi školami a centrem (buffer); 3) podporovat spolupráci mezi školami; 4) monitorovat dosažené změny; 5) sdílet a integrovat změny mezi různými školami; 6) mírnit odpor dané komunity ke změně.

Pokud jde o prakticky orientovaný proud, zvláštní pozornost si zaslouží především koncepce tzv. vedení ze středu (leading from the middle, LfM; Hargreaves \& Shirley, 2020), která byla v poslední době zpopularizována i v České republice (Hargreaves \& Ainscow, 2020). Tento přístup se snaží minimalizovat negativní aspekty SČ a odlišit 
se od konceptu vedení ve středu (leading in the middle, LiM; Barber \& Day, 2014). To, co je pro koncept LfM klíčové, je, že školské obvody zde nemají plnit pouze roli prostředníků, kteří zavádějí a řídí průběh reforem, které navrhl někdo jiný. Nejde o vykonávání příkazů a doporučení shora. V tomto vnímání jsou školské obvody kolektivní hybnou silou změn a zvyšování kvality. Reagují na místní potřeby a odlišnosti, přebírají kolektivní odpovědnost za úspěch všech studentů i ostatních obvodů, realizují vlastní iniciativu. Místo toho, aby „pouze“ implementovaly iniciativy někoho jiného, zapojují vlastní snahy do širších systémových priorit a vytvářejí transparentní zapojení aktérů a výsledků.

\section{Odlišná pojetí středního článku}

V části pojednávající o SČ v různých vzdělávacích systémech jsem představil tři možné podoby SČ. Zároveň jsem ovšem ukázal, že jde o velmi hrubé kategorie, které lze využít pro základní orientaci, ale nikoli pro strukturovanou odbornou debatu. Pro tu je potřeba přesnějšího vymezení, o které se pokusím v této kapitole. V návaznosti na provedený rozbor literatury doporučuji rozlišovat mezi čtyřmi různými významy sč. Definuji je následovně (pro usnadnění je označuji čísly a zkráceným názvem):

- Definice 1 - SČ jako volná sít' místních aktérů. Střední článek představuje sít' aktérů mezi konkrétní školou a centrem (ministerstvem školství), kteři se zabývají podporou nebo vedením (leadership) více škol působících v určitém územním celku, menším, než je celý stát.

- Definice 2 - SČ jako koordinovaný a interagující systém aktérů (široké pojetí školského obvodu). Střední článek zahrnuje komplexní systém interagujících aktérů propojených do formálních a neformálních sítí v daném území, jejichž hlavním a společným úkolem je podpora, řízení nebo vedení více škol.

- Definice 3 - SČ jako místně organizované uskupení několika klíčových organizací (užší pojetí školského obvodu). Střední článek představuje samostatně ustavenou a působící organizaci nebo uskupení několika organizací, jejichž působnost je omezena na konkrétní území a jejichž hlavním úkolem je podpora, řízení nebo vedení více škol.

- Definice 4 - SČ jako dekoncentrovaná instituce veřejné správy. Střední článek představuje územní orgán veřejné správy, jehož úkolem je podpora, řizení nebo vedení více škol.

Všechny výše uvedené definice mají některé znaky společné. Všechny předpokládají, že SČ může nabývat různých velikostí (od velmi malých až po velké územní celky), různých forem (tj. nemusí jít o instituce, které jsou zřizovány výlučně pro školy, ale může jít i o součásti organizací zřizovaných i za jiným účelem) a různých rolí (tj. zahrnuje jak organizace řídící, tak podpůrné). V dalších ohledech se již ovšem liší.

Rozeberme si nyní výše uvedené definice podrobněji. První a nejobecnější definice je dostatečně široká na to, aby obsáhla velmi různorodé podoby Sč. Dưležité 
v této obecné definici je, že jde o sít' (nikoli ale „systém“) aktérů, což zahrnuje i vztahy mezi těmito jednotlivými aktéry a jejich propojení. I když se jedná o definici velmi širokou, nejde o definici bezbřehou, nebot' vylučuje jak např́klad organizace zřizované jen pro jednu školu, tak organizace s celostátní působností. ${ }^{8}$ Tato definice má blízko k chápání SČ jako volné sítě a partnerství řady aktérů a organizací na střední úrovni, a to bez nějaké ústřední organizace v daném území. Bez ohledu na organizaci řizení vzdělávání (tedy např. na to, zda existují - či neexistují - školní obvody a nakolik je systém decentralizovaný) ve většině zemí nacházíme aktéry a organizace kooperující mezi konkrétní školou a centrem, kteří mají na školy v daném území vliv. Nejsou zřizované výlučně za účelem podpory či vedení škol, přesto mohou významně ovlivňovat podobu vzdělávání v daném území. Důležité ovšem je, že v rámci tohoto vymezení představuje SČ spontánně a odspoda vznikající sít' institucí, nikoli záměrně vytvořený systém podpory nebo vedení na střední úrovni.

Druhá a třetí definice vycházejí z představy školského obvodu a zároveň odrážejí odlišnosti v př́stupech $\mathrm{k}$ jejich vymezení. Druhá definice je širší a v podstatě odpovídá definici školských okrsků v USA dle Sykese et al., kteří uvádějí, že školské okrsky

zahrnují více než centrální úřad nebo místní školskou radu (ačkoli jde samozřejmě o hlavní iniciátory místní školské politiky), přičemž jde o celý komplexní systém interagujících aktérů (učitelů, úřredníků, studentů, podpưrného personálu, rodičů), jednotek (škol, odborů, formálních a neformálních sítí), rolí a účelů. $(2009$, s. 767)

Uvedení autoři nepopírají klíčovou roli místního úřadu a volené reprezentace v daném území, ale za SČ nepokládají „jen“ formální organizace a reprezentanty daného území. Toto široké pojetí školského distriktu jako komplexního a koordinovaného systému organizací a jeho neztotožnění s konkrétním úřadem má široké teoretické i praktické implikace.

Třetí definice je $z$ hlediska svého záběru užší a omezuje se na ty organizace, které jsou zřizovány prímo za účelem podpory nebo vedení škol v rámci určitého území. Blízko k tomuto pojetí mají např́iklad Rorrerová et al., když vymezují školské obvody jako „organizované uskupení (organized collective) tvořené superintendantem, školskou radou, ústředním úřadem a řediteli, kteří kolektivně propojují školu a školský obvod“ (2008, s. 311). Druhá a třetí definice se nevylučují. V závislosti na daném účelu je možné vymezovat školský obvod šířeji (jako všechny působící organizace a aktéry, včetně jejich sítí), nebo úžeji (jako organizace přímo a formálně odpovědné za dané území). Jde pouze o úhel pohledu. $V$ realitě existuje oboje: jak klíčové organizace reprezentující a formálně zodpovídající za dané území (např. školská rada a superintendant), tak všechny další organizace a aktéři, kteří se na vzdělávání v daném území spolupodílejí. Odlišení těchto dvou pojetí je ovšem pro porozumění si ve vzájemných diskusích velmi důležité.

U federálních států (Německo, Kanada, USA atd.) existuje ještě jedna úroveň rízení vzdělávací politiky (spolková země, provincie, stát), kterou pro účely tohoto článku budeme považovat za „celostátní působnost“. 
Čtvrtá definice je z hlediska svého významu nejužší. Za střední článek je zde považována jedna organizace, která je zpravidla součástí veřejné správy. Do této definice je zahrnut obzvláště SČ v centralizovaných systémech. Spadají sem ovšem také školské úřady $\vee$ České republice $v$ letech 1990-2000, kdy byly rozpočtovými organizacemi ř́zenými prímo ministerstvem. $V$ pojmosloví teorie veřejné správy šlo o územní dekoncentráty, tedy podřízené správní úrady s územní (místní) pưsobností.

Výše uvedená klasifikace je záměrně abstraktní. To znamená, že jednotlivé typy nelze jednoduše ztotožnit s podobou SČ v konkrétních zemích, protože ta se mǔže lišit i uvnitř těchto zemí. To lze ukázat na príkladu zemí, kde školy zřizují přímo města a obce (jako je tomu i $v$ České republice). Pokud obce nevytvářejí pro školy žádné podpůrné kapacity, lze hovořit o prvním typu SČ. V případě, že takové kapacity města a obce tvoří, je možné takový systém zařadit do druhého nebo třetího typu.

\section{Závěry a některé implikace}

Role SČ je jedním z ústředních témat současné vzdělávací politiky. Jak jsme viděli, názory oscilují od jednoznačně pozitivního vidění role SČ (Campbell \& Fullan, 2019; Hargreaves \& Shirley, 2020) až po značně kritické (Lubienski, 2014). Řada zemí v poslední době prošla nebo prochází proměnou role SČ (González et al., 2020; Greany \& Higham, 2018). $\mathrm{K}$ těmto zemím se nově řadí i Česká republika, kde se pilotování a zavádění SČ staly ústředními tématy aktuální vzdělávací politiky (MŠMT, 2021).

Od zavádění SČ si ovšem různí aktéři slibují velmi odlišné věci, což je dáno i tím, že pojem SČ je užíván ve značně odlišných významech. Shoda nepanuje především $v$ tom, zda má jít spíše o střední článek podpory, nebo řízení.

Modely přítomné $v$ debatě mají podobu od jednoznačně centralistického řešení s ministerstvem řízenými detašovanými pracovišti přes posílení koordinačních kapacit coby středního článku $v$ krajích, okresní uspořádání ve více variantách či institucionalizování stávajících místních akčních plánů ve struktuře ORP (Hřebecký, 2021, s. 13).

Dalším problémem je velmi selektivní a někdy i nekritické využívání (nejen) odborné literatury na toto téma. Podobně jako u jiných opatření v oblasti vzdělávací politiky zde přitom platí, že pokud si přesně nevyjasníme cíl politiky a způsob jeho dosažení, je vysoce pravděpodobné, že tato politika bude neúspěšná. Zatímco ve strategických dokumentech lze myšlenkové nedotaženosti do jisté míry skrýt pod obecnými proklamacemi, ve fázi implementace vyjdou všechny tyto nejasnosti žretelně na povrch. Pokud totiž bude SČ skutečně zaváděn, bude třeba vyřešit řadu konkrétních věcí. Jaké činnosti má vykonávat, aby měly co největší pozitivní dopad na učení žáků? Jak by měl být SČ nastaven, aby dokázal přitáhnout místní pedagogické lídry a udržet je mezi svými zaměstnanci? Jakou má mít právní formu, kompetence a odpovědnosti? Jaký bude jeho vztah k ostatním institucím a aktérům? Jaký status budou mít jeho zaměstnanci a odkud (a jak) se budou přijímat? 
Na řadu těchto otázek jistě nelze v tuto chvíli odpovědět a je potřeba je nejprve dostatečně prodiskutovat. Pokud si však již nyní neujasníme vzájemné představy o optimální podobě sč, čekají nás nevyhnutelně zbytečná nedorozumění. Výše uvedená čtyři vymezení SČ přitom zhruba odpovídají také různým možným podobám Sč. Nejde sice o pojetí nutně zcela kontradiktorní, ale bezesporu jde o značně odlišné představy o SČ. Stávající diskuse ovšem tyto zásadní odlišnosti často pomíjejí a v důsledku toho dochází (a bude docházet) k řadě nedorozumění. Představy a vymezení sč jsou navíc přitom často pouze implicitní. Pro úspěch implementace považujeme za zcela nezbytné, aby tyto diskuse explicitně pracovaly s nějakou podobou středního článku.

Jde například o zásadní rozdíl $v$ tom, zda chceme směřovat $\mathrm{k}$ podobě školského obvodu (definice 2 a 3), nebo k podobě připomínající školské úřady (definice 4). Je samozřejmě možné uvažovat i o nějaké postupné změně a kombinaci výše uvedeného, například dobudování středního článku státní správy (definice 4), postupný vznik školského obvodu s několika klíčovými institucemi (definice 3) a postupné rozšiřování záběru a významu Sč až $\mathrm{k}$ široce sdílené odpovědnosti řady aktérů v rámci daného území (definice 2).

Druhou implikací z provedeného přehledu je, že na myšlenku SČ je potřeba se dívat s jistým kritickým odstupem. Jednou z nevýhod a omezení současných diskusí, včetně této stati, je zaměření se na anglicky psanou literaturu, která do jisté míry vede i k omezení geografického záběru na země s odlišnou historickou tradicí. V dosavadních úvahách je SČ někdy vykreslován jako všelék, který po svém zavedení automaticky povede ke zlepšení kvality vzdělávání i snížení vzdělanostních nerovností. SČ ovšem není a nemůže být samospasitelný. Ostatně změna organizačních struktur sama o sobě nemá na učení žáků a studentů žádný přímý vliv (March, 1978).

Zkušenosti se školskými obvody - kromě pozitiv - ukazují také na omezení a problémy SČ. Předně, ne všechny školské obvody mají dostatečné kapacity a zdroje k efektivnímu vedení a v kvalitě školských obvodů existují často neodůvodněné rozdíly (Hargreaves \& Ainscow, 2020). Školské obvody také nejsou imunní vưči tradičním problémům všech organizací: zkostnatění, samoúčelnosti, záměně cílů nebo politikaření. Tak jako vždy, klíčové jsou personální obsazení a kultura organizace.

S tím souvisí i další problém, a to je nekritické a výběrové přejímání poznatků a zkušeností ze zahraničí. Debata u nás je často inspirovány zkušenostmi z USA, Kanady či Velké Británie, protože literatura pojednávající o těchto zemích je nejpočetnější a nejlépe dostupná. Jak je ovšem patrné i z rozboru v tomto textu, podoba školských obvodů v anglosaských zemích se zásadně liší od nejen současného, ale také předcházejícího nastavení organizace vzdělávání u nás (včetně formy, jakou měly školské tuzemské úřady v letech 1990-2000). Školské obvody, jak je známe z USA či Kanady, u nás nikdy neexistovaly, a není tedy na co navazovat. Jak jsem popsal výše, školské obvody mají v těchto zemích výraznou samosprávnou složku a tradičně vznikaly odspodu. Je velká otázka, do jaké míry a za jakých podmínek je tato tradice přenositelná do kontextu České republiky. 
52 Pilotní ověření a následné zavádění SČ představují jednu z největších výzev vzdělávací politiky v České republice $v$ nejbližších letech. Může jít o změnu, která zásadním způsobem promění kvalitu vzdělávání v České republice $\mathrm{k}$ lepšímu. Je ovšem také možné, že celá myšlenka nebude dovedena do úspěšné implementace, nebo $v$ průběhu implementace zcela změní svoji podobu. Každopádně sledováni a vyhodnocení procesu pilotování a zavádění Sč jsou i velkým vzdělávacím experimentem, který by měl být jedním z důležitých témat pedagogického výzkumu $v$ príštích letech.

\section{Poděkování}

Tato studie vznikla v rámci projektu Partnerství pro vzdělávání 2030+, který je realizován díky finanční podpoře Nadace České spořitelny a Nadace RSJ.

\section{Literatura}

Anderson, E., \& Young, M. (2018a). A research-based framework for district effectiveness. UCEA Review, 59(3), 2-12.

Anderson, E., \& Young, M. (2018b). If they knew then what we know now, why haven't things changed? An examination of district effectiveness research. Frontiers in Education, 3(87). https://doi.org/10.3389/feduc.2018.00087

Aston, H., Easton, C., Sims, D., Smith, R., Walker, F., Crossley, D., \& Crossley-Holland, J. (2013). What works in enabling school improvement? The role of the middle tier. NFER.

Barber, M., \& Day, S. (2014). The new opportunity to lead: A vision for education in Massachusetts in the next 20 years. Massachusetts Business Alliance for Education.

Bubb, S., Crossley-Holland, J., Cordiner, J., Cousin, S., \& Earley, P. (2019). Understanding the middle tier comparative costs of academy and LA-maintained school systems. Sara Bubb Associates.

Burns, T., \& Köster, F. (Eds.). (2016). Governing education in a complex world. OECD.

Burns, T., Köster, F., \& Fuster, M. (2016). Education governance in action: Lessons from case studies. OECD.

Campbell, D., \& Fullan, M. (2019). The governance core: School boards, superintendents, and schools working together. Corwin Press.

Clune, W. H. (1987). Institutional choice as a theoretical framework for research on educational policy. Educational Evaluation and Policy Analysis, 9(2), 117-132. https://doi .org/10.2307/1163725

Crawford, M., Maxwell, B., Coldron, J., \& Simkins, T. (2020). Local authorities as actors in the emerging "school-led" system in England. Educational Review, 1-17. https://doi.org/10 $.1080 / 00131911.2020 .1739625$

Elmore, R. F. (1993). The role of local school districts in instructional improvement. In S. H. Fuhrman (Ed.), Designing coherent education policy: Improving the system (s. 96-124). Jossey-Bass Publishers.

Elmore, R. F. (1996). Getting to scale with good educational practice. Harvard Educational Review, 66(1), 1-27.

Elmore, R. F. (2016). „Getting to scale...“" it seemed like a good idea at the time. Journal of Educational Change, 17(4), 529-537.

Ford, T. G., Lavigne, A. L., Fiegener, A. M., \& Si, S. (2020). Understanding district support for leader development and success in the accountability era: A review of the literature using 
social-cognitive theories of motivation. Review of Educational Research, 90(2), 264-307. https: / /doi.org/10.3102/0034654319899723

Forde, C., \& Torrance, D. (2021). Leadership at all levels: System alignment through empowerment in Scottish education? School Leadership and Management, 41(1-2), 22-40. https:// doi.org/10.1080/13632434.2020.1825372

Fullan, M. (2015). Leadership from the middle: A system strategy. Education Canada, 55(4), 22-26.

Gamson, D. A., \& Hodge, E. M. (2016). Education research and the shifting landscape of the American school district, 1816 to 2016. Review of Research in Education, 40(1), 216-249. https: / /doi.org/10.3102/0091732X16670323

Glatter, R. (2021). The 'independent state school' and its aftermath: Implications for the processes and structures surrounding school leadership. School Leadership and Management, 41(1-2), 93-116. https://doi.org/10.1080/13632434.2020.1814236

González, Á., Ehren, M., \& Montecinos, C. (2020). Leading mandated network formation in Chile's new public education system. School Leadership and Management, 40(5), 425-443. https: / / doi.org/10.1080/13632434.2020.1783649

Greany, T. (2020). Place-based governance and leadership in decentralised school systems: Evidence from England. Journal of Education Policy, 1-22. https://doi.org/10.1080/0268 0939.2020.1792554

Greany, T., \& Higham, R. (2018). Hierarchy, markets and networks: Analysing the'self-improving school-led system'agenda in England and the implications for schools. UCL Institute of Education.

Hargreaves, A., \& Ainscow, M. (2015). The top and bottom of leadership and change. Phi Delta Kappan, 97(3), 42-48. https://doi.org/10.1177/0031721715614828

Hargreaves, A., \& Ainscow, M. (2020). Vedení ze středu. SKAV. https://uspechzaka.cz/wp/wp -content/uploads/2020/06/UPKZ_clanek_Vedeni-ze-stredu_kveten2020_A4_5_FINAL.pdf

Hargreaves, A., \& Shirley, D. (2020). Leading from the middle: Its nature, origins and importance. Journal of Professional Capital and Community, 5(1), 92-114.

Hřebecký, M. (2019). Hledání obsahu role zřizovatele aneb Čí je škola a kdo ji řídí? Řízení školy, 16(7-8), 6-10.

Hřebecký, M. (2021). Odkud a proč se vzala myšlenka středního článku. Řízení školy, 18(4), 12-14.

Chapman, C. (2019). From hierarchies to networks: Possibilities and pitfalls for educational reform of the middle tier. Journal of Educational Administration, 57(5), 554-570. https:// doi.org/10.1108/JEA-12-2018-0222

Chapman, C., \& Hadfield, M. (2010). Supporting the middle tier to engage with school-based networks: Change strategies for influencing and cohering. Journal of Educational Change, 11(3), 221-240.

Kitzberger, J. (2019). Dlouhá trat' opuštěnou krajinou aneb „Potřebujeme střední článek řízení?“. Řízení školy, 16(9), 36-37.

Leithwood, K. (2010). Characteristics of school districts that are exceptionally effective in closing the achievement gap. Leadership and Policy in Schools, 9(3), 245-291.

Leithwood, K. (2013). Strong districts \& their leadership. Paper commissioned by the Council of Ontario Directors of Education and the Institute of Education Leadership.

Leithwood, K., Sun, J., \& McCullough, C. (2019). How school districts influence student achievement. Journal of Educational Administration, 57(5), 519-539. https://doi .org/10.1108/JEA-09-2018-0175

Levin, B. (2013). Do we need school districts? Phi Delta Kappan, 94(5), 74-75. https://doi .org/10.1177/003172171309400519

Lubienski, C. (2014). Re-making the middle: Dis-intermediation in international context. Educational Management Administration \& Leadership, 42(3), 423-440. https://doi .org/10.1177/1741143214521594

Mareš, J. (2013). Přehledové studie: Jejich typologie, funkce a způsob vytváření. Pedagogická orientace, 23(4), 427-454. http://dx.doi.org/10.5817/PedOr2013-4-427 
54 March, J. G. (1978). American public school administration: A short analysis. The School Review, 86(2), 217-250.

Mourshed, M., Chijioke, C., \& Barber, M. (2010). How the world's most improved school systems keep getting better. McKinsey \& Company.

MŠMT. (2020). Strategie vzdělávací politiky České republiky do roku 2030+. MŠMT. https:// www.msmt.cz/vzdelavani/skolstvi-v-cr/strategie-2030

MŠMT. (2021). MŠMT zahájilo pilotáž středního článku podpory. MŠMT. https://www.edu.cz /stredni-clanek-podpory/

Murphy, J., \& Hallinger, P. (1988). Characteristics of instructionally effective school districts. The Journal of Educational Research, 81(3), 175-181. https://doi.org/10.1080/00220671 .1988 .10885819

Neeleman, A. (2019). The scope of school autonomy in practice: An empirically based classification of school interventions. Journal of Educational Change, 20(1), 31-55.

Nordholm, D. (2016). State policy directives and middle-tier translation in a Swedish example. Journal of Educational Administration, 54(4), 393-408. https://doi.org/10.1108/JEA-05 $-2015-0036$

OECD. (2018). How decentralised are education systems, and what does it mean for schools? Education Indicators in Focus, 64. https://www.oecd-ilibrary.org/content/paper /e14575d5-en

Parkin, T. (2012). Do we need a middle tier in education? Forum, 54(1), 37-40. https://doi .org/10.2304/forum.2012.54.1.37

Payne, C. M. (2008). So much reform, so little change: The persistence of failure in urban schools. Harvard Education Press.

Rorrer, A. K., Skrla, L., \& Scheurich, J. J. (2008). Districts as institutional actors in educational reform. Educational Administration Quarterly, 44(3), 307-357. https://doi .org/10.1177/0013161X08318962

Schiltz, F., \& De Witte, K. (2017). Estimating scale economies and the optimal size of school districts: A flexible form approach. British Educational Research Journal, 43(6), 1048-1067. https://doi.org/10.1002/berj.3312

Schleicher, A. (2015). Schools for 21st-century learners: Strong leaders, confident teachers, innovative approaches. OECD. https://www.oecd.org/publications/schools-for-21st -century-learners-9789264231191-en.htm

Simkins, T., Coldron, J., Crawford, M., \& Jones, S. (2015). Emerging local schooling landscapes: The role of the local authority. School Leadership and Management, 35(1), 1-16. https://doi.org/10.1080/13632434.2014.962501

Slejška, Z. (2020). Eduzměna: Jak jsme vybírali co nejvhodnější region. Řízení školy, 17(4), 38-39.

Snyder, S. (2013). The simple, the complicated, and the complex: Educational reform through the lens of complexity theory. OECD.

Spillane, J. P. (1996). School districts matter: Local educational authorities and state instructional policy. Educational Policy, 10(1), 63-87. https://doi.org/10.1177/0895904896010001004

Sykes, G., O’Day, J., \& Ford, T. G. (2009). The district role in instructional improvement. In G. Sykes, B. Schneider, \& D. N. Plank (Eds.), Handbook of education policy research (s. 767-784). Routledge.

Trojan, V. (2020). Ředitel a zřizovatel aneb Láska za časů cholery. Řizení školy, 17(5), 47-48.

Veselý, A. (2019). Od samozřejmosti ke spoluodpovědnosti. Proměny ve vnímání veřejných služeb. In P. Hlaváček (Ed.), Nesamozřejmý národ? Reflexe českého třicetiletí 1989-2019 (s. 301-311). Academia.

Veselý, A., Fischer, J., Jabůrková, M., Pospišil, M., Prokop, D., Sáblík, R., Stuchlíková, I., \& Štech, S. (2019). Hlavní směry vzdělávací politiky ČR do roku 2030+. MŠMT. http: //www.msmt .cz/file/51582_1_1/

Whelan, F. (2009). Lessons learned: How good policies produce better schools. Fenton Whelan.

Wilkoszewski, H., \& Sundby, E. (2014). Steering from the centre: New modes of governance in multi-level education systems. OECD. 
prof. PhDr. Arnošt Veselý, Ph.D.

Institut sociologických studií \& Centrum pro sociální a ekonomické strategie

Fakulta sociálních věd, Univerzita Karlova Smetanovo nábřeží 6, 11001 Praha 1 veselya@fsv.cuni.cz 